(564)

レーザーオリジナル

$$
\begin{gathered}
\text { 紫外レーザーを用いたレーザー誘雷 } \\
\text { 一エキシマレーザーの放電誘導特性一 } \\
\text { 三木 恵*·和田 } \text { 淳 }^{*} \cdot \text { 新藤 }
\end{gathered}
$$

（1996 年 3 月 21 日 受理）

\title{
Artificial Triggered Lightning Using Ultraviolet Lasers - Guiding of the Electrical Discharges by an Excimer Laser -
}

\author{
Megumu MIKI*, Atsushi WADA* and Takatoshi SHINDO*
}

(Received March 21, 1996)

\begin{abstract}
Guiding and triggering of the electrical discharges in $1 \mathrm{~m}$ air gaps by excimer lasers $(\mathrm{KrF}(\lambda=248 \mathrm{~nm}), \operatorname{ArF}(\lambda=193 \mathrm{~nm}))$ have been performed. A laser pulse ( $\mathrm{KrF}: 750 \mathrm{~mJ}, \mathrm{ArF}: 550 \mathrm{~mJ})$ produced a plasma channel over a distance of more than $0.5 \mathrm{~m}$ by focused with a lens. Characteristics of guided discharges along the plasma channel were investigated in detail. From these results, it is found that an excimer laser pulse can guide the positive discharges and propagate in the plasma channel produced by itself without loss. However the excimer lasers have little ability to trigger the discharges. Further the guiding ability is not maintained for a long time compared with that of infrared lasers. On the basis of these experimental results, we discussed the basic concept of the laser triggered lightning with an excimer laser.
\end{abstract}

Key Words: Excimer laser, Laser-produced plasma, Laser-guided discharge, Lightning

1.はじめに

近年, 日本を中心としてレーザー誘雷の研究 が活発に進められている。特に誘雷の基礎研究 として高電圧発生装置を用いた放電誘導実験が 多くの研究機関にて実施されている。 レーザーは電離チャネル(プラズマ)を生成する
ことによってはじめて放電を誘導することがで きる。このようなプラズマ生成のためには, レー ザーのピークパワーが一定のしきい值より高い 必要がある。プラズマ生成のピークパワーのし きい值はレーザーの波長により変化し, 赤外領 域および紫外領域が低い1)。よって，これらの波 長領域のレーザーがプラズマ生成には適してい

* (財) 電力中央研究所 雷放電グループ（ 201 狛江市岩戸北 2-11-1）

* Lightning discharge group, Central Research Institute of Electric Power Industry (11-1 Iwadokita 2-Chome, Komae, Tokyo 201) 
ると言える。さらにプラズマの大きさや電子温 度等のパラメータはパルスエネルギーに依存し ている。放電を誘導するためには長い距離にわ たってプラズマを生成する必要があるため, パ ルスエネルギーは大きい方がよい。一般に $\mathrm{CO}_{2}$ レーザーのような赤外レーザーは, プラズマ生 成のピークパワーのしきい值が低く，また比較 的容易にパルスエネルギーを上げられることか ら, 放電誘導実験には多く用いられている。その ため，赤外レーザーでは既に数 $\mathrm{m}$ 以上の長 ギャップにおける放電誘導の実験が内外ともに 多く報告されており，そのメカニズムも解明さ れつつある2-6)。

一方, 紫外レーザーでは, 数 $10 \mathrm{~cm}$ 程度のギャッ プでさえ大気中における放電誘導実験の報告は 極めて少ない7-9)。これは紫外レーザーでは赤外 レーザーのように容易にパルスエネルギーを上 げられないので, 長い距離にわたってプラズマ チャネルを気中に生成するのがこれまで困難 だったためと考えられる。しかし, 紫外レーザー はプラズマに吸収, 散乱されにくいため, 長いプ ラズマチャネルを生成するのには適している。 紫外レーザーによる長距離プラズマチャネルの 応用例としては加速器中の電子ビームの伝搬経 路の制御 (ガイド) がある10)。この応用では, 既 に $90 \mathrm{~m}$ 以上の距離にわたるプラズマの生成と電 子ビームのガイドが報告されている11)。その他, 電子ビームの制御の研究においてはギャップ長 $0.6 \mathrm{~m}$ の低気圧放電管内の放電をレーザービーム に沿って発生させ，スパークオーバ電圧を最大 30\% まで低下させたことが報告されている12)。 またレーザートリガギャップの実験においても 紫外レーザーは赤外レーザーと比べてはるかに 少ないエネルギーで放電を誘発出来るという結 果が報告されている13)。これらの実験結果から 紫外レーザーには放電路を制御する能力（放電 ガイド効果) やスパークオーバ電圧を低下させ る能力 (放電トリガ効果) があることが期待でき る。以上より長距離にわたり放電を誘導する必 要がある。レーザー誘雷には紫外レーザーが有 利であると考えられる。

著者らは比較的パルスエネルギーが大きく, ビーム拡り角の小さいエキシマレーザーを用い
て, 長尺プラズマチャネルを生成した。なお, 出 来るだけ長い距離に亘る効率的なプラズマチャ ネルの生成のため, 実験では長焦点の石英レン ズを用いてレーザーパルスを弱収束させ, 光学 的絶縁破壊を伴わないプラズマチャネルを生成 した。さらに,インパルス電圧発生装置により生 成した気中放電の誘導を試みた。その結果, 最大 $1 \mathrm{~m}$ のギャップにて放電誘導に成功した。また, このような紫外レーザーにより誘導された放電 の測定を詳細に行い, その結果を基に紫外レー ザーによる誘雷システムについての検討を行っ た。

\section{2. 実験装置}

Fig. 1 に実験系の概要を示す。使用したレー ザーはエキシマレーザー(Lambda Physik 社製, LPX150)であり, 設定の変更により ArFレーザー (波長 $=193 \mathrm{~nm}$ :パルスエネルギー $=550 \mathrm{~mJ})$ と KrF レーザー (波長 $=248 \mathrm{~nm}$ : パルスエネルギー= $750 \mathrm{~mJ})$ の発振が可能である。ビーム発散角はい ずれも $0.2 \mathrm{mrad}$ 以下である。レーザーは石英レン ズによりギャップ中に集光され，プラズマを生 成する(Fig. 2)。プラズマは青く発光するチャネ ルであり, 基本的には光学的絶縁破壊を伴なっ ていない。一部小さな白色光が見えるが,これは 空気中の塵のため生成された光学的絶縁破壊を 伴ったプラズマである。高圧電極にはインパル ス電圧発生器により雷インパルス電圧 $(1 \times 40 \mu \mathrm{s})$ を印加した。使用したインパルス電圧発生器は 最大印加電圧が $1 \mathrm{MV}$, 最大蓄積エネルギーが $5 \mathrm{~kJ}$ である。インパルス電圧の印加とレーザー照射 のタイミングは任意に設定可能であり, 本論文 ではこのレーザー照射と電圧印加の時間間隔を 遅れ時間と呼ぶことにする。ここで, 遅れ時間が 正とは, レーザー照射が電圧印加より早い場合

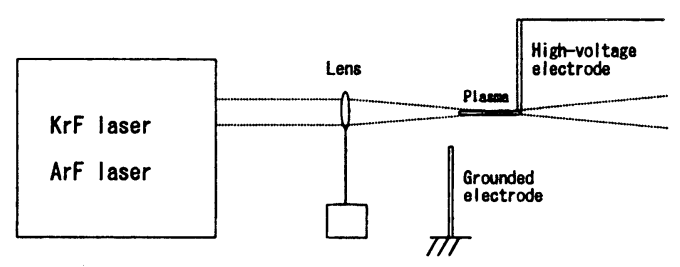

Fig. 1 Experimental setup. 


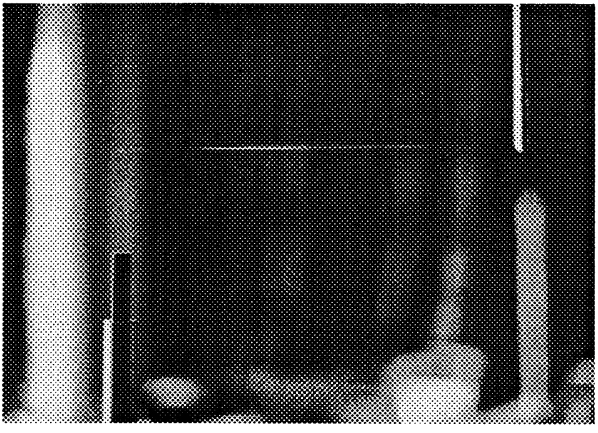

Fig. 2 Plasma channel produced by a $\mathrm{KrF}$ laser pulse (wavelength $=248 \mathrm{~nm}$, pulse energy $=750 \mathrm{~mJ}$ ).

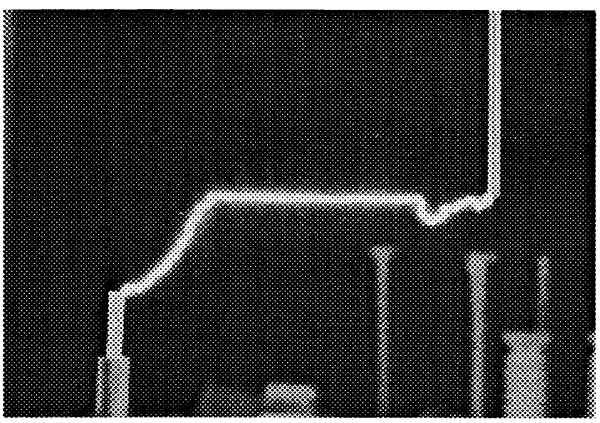

Fig. 3 Electrical discharge guided by a plasma channel for positive polarity (gap length $=0.33 \mathrm{~m}$ ).

であり，遅れ時間が負とはレーザー照射が電圧 印加より遅れる場合を示す。ここでFig. 3にレー ザーにより誘導された放電の代表的な例を示す。 この時のギャップ長は水平方向 $(x) に 32.5 \mathrm{~cm}$, 垂 直方向 $(y)$ に $10 \mathrm{~cm}$ であり,レーザーは焦点距離 $1 \mathrm{~m}$ (@ $\lambda=546.1 \mathrm{~nm})$ のレンズにより集光している。ま

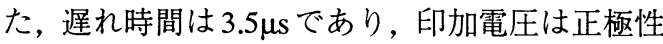
で $220 \mathrm{kV}$ である。放電チャネルが直線的に形成 されている部分は放電がレーザー生成プラズマ に誘導された部分である。この長さは放電ガイ ド効果の指標となるので本論文ではこの長さを 放電ガイド長と呼ぶ。

\section{3. 実験結果}

\section{1 遅れ時間と放電誘導効果}

紫外レーザーによる放電のガイド効果につい て調べるため，放電ガイド長と遅れ時間の関係 を調べた(Fig. 4)。ギャップの設定はFig. 3 の写真 と同じである。実験はKrFレーザーの正極性と負

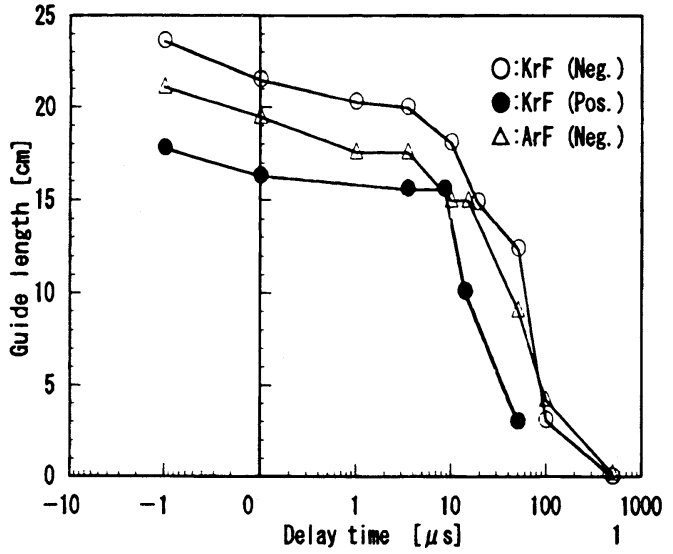

Fig. 4 Delay time characteristics of the guide length. Guide length is the length of the discharge channel formed along the laser beam.

極性の 2 つの場合と ArF レーザーの負極性の場 合について行った。デー夕は約 35 shots のデー夕 の平均值である。Fig. 4の結果は $\mathrm{KrF}$ と ArFでは 放電ガイド長には大きな差がないことを示して いる。パルスエネルギーは K r F レーザーが 750mJ, ArFレーザーが550mJであるので，エネ ルギー差を考えれば ArF の方が放電誘導の工ネ ルギー効率はよいと言える。また基本的な特性 はほほ同じであり，いずれにおいても遅れ時間 が $10 \mu \mathrm{s}$ 以上になると放電誘導能力が低下してい る。この図は紫外レーザーにより生成されたプ ラズマもその放電誘導特性に極性効果があるこ とを示しており，負極性放電が正極性放電より 誘導されやすいことがわかる。この実験では ギャップを非対称にしてあるので, 正極性, 負極 性の結果はそれぞれ正リーダ，負リーダとレー ザー生成プラズマとの相互作用を示している。 放電ガイド長が最も長かったのは，負極性では 遅れ時間がー1 間が短い方がガイド長が長かったが，-1 では大きな差はなかった。この結果から電圧を 先に印加したときの方が電圧を後から印加する より誘導効果がよいことがわかる。但し, 印加電

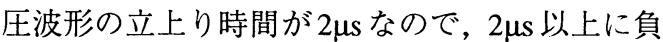
の遅れ時間が大きくなると放電ガイド長は減衰 する。

紫外レーザーによるスパークオーバ電圧の低 下を調べるため，Fig. 3のギャップ配置にて 50\% 
スパークオーバ電圧の測定を行い，レーザー照 射がない放電との比較を行った。測定手法は試 行回数 10 回の補間法を用いた。負極性では遅れ 時間一 $1 \mu \mathrm{s}$ の設定で最もスパークオーバ電圧が低 下し, レーザーの照射がなかった場合と比べて 約 $15 \%$ 低下した。しかし, 遅れ時間が $0 \mu$ 以上で はスパークオーバ電圧の低下はほとんどみられ なかった。また正極性においては遅れ時間 $3.5 \mu \mathrm{s}$ のときが最も低下し，約 15\%の低下が見られた。 しかし, 遅れ時間が $10 \mu \mathrm{s}$ では既にスパークオー バ電圧の低下はなかった。この実験結果より, 紫 外レーザーにより生成されたプラズマチャネル は赤外レーザーにより生成されたプラズマチャ ネルに比ベスパークオーバ電圧を低下させる能 力が低いことが分かった。

\section{2 放電ガイド長ーギャップ長特性}

ギャップ長を変化させた場合の放電ガイド長 を測定した(Fig. 5)。ギャップ長は水平方向の長 さのみを変化させた。プロットは約20shotsの平 均值である。遅れ時間は $-1 \mu \mathrm{s}$ に設定したが, 比

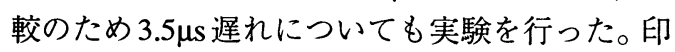
加電圧はレーザーを照射しない場合の $50 \%$ ス パークオーバ電圧である。ArFレーザーでは焦点

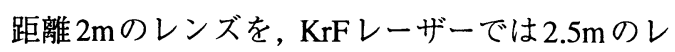
ンズを使用した。ただし，ギャップ長 $32.5 \mathrm{~cm}$ の ときのデー夕は焦点距離 $1 \mathrm{~m}$ のレンズによるもの である。ギャップ長が長くなるにつれガイド長 は $0.5 \mathrm{~m}$ 程度で飽和してくる。これは放電を誘導

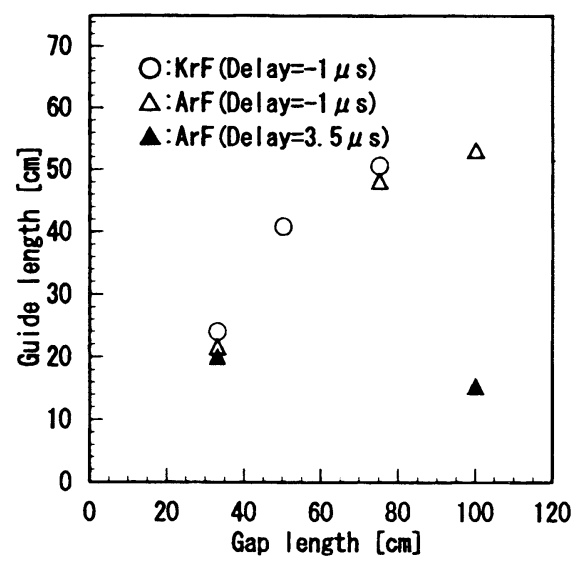

Fig. 5 Guide length vs gap length characteristics.

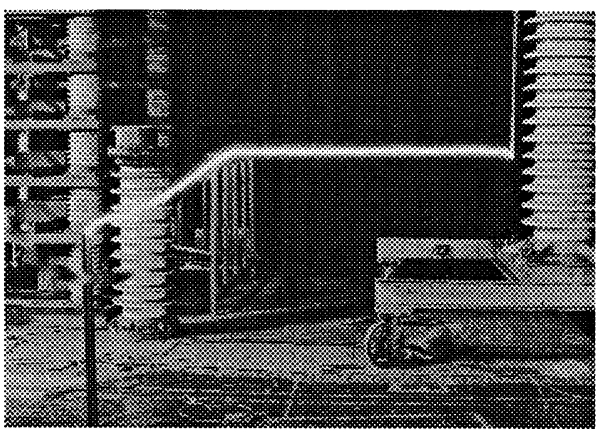

Fig. 6 Electrical discharge guided by an ArF laser pulse in a $1 \mathrm{~m}$ air gap with negative polarity. (Delay time: $-1 \mu \mathrm{s}$ )

出来るプラズマチャネルの長さよりギャップ長 が長くなり, ギャップ長が増えても放電ガイド 長は増加しなくなるためである。この飽和によ る漸近值が放電誘導可能なプラズマチャネルの 全長を示していると考えられる。この特性では $\mathrm{KrF}$ レーザーと ArF レーザーはほほ同じであり， 最大の放電ガイド長は共に $0.5 \mathrm{~m}$ 程度になると評

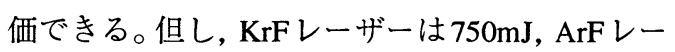
ザーは $550 \mathrm{~mJ}$ とパルスエネルギーが異なってい ることを考えると, ArFレーザーの方が若干誘導 の効率がよいと言える。またArFレーザーの遅れ 時間が3.5 $\mu$ のデータから, ギャップが長いと時 間経過に伴うプラズマの放電誘導能力の減衰が 大きいことがわかる。これより, 放電誘導効果を 長時間にわたり持続しているプラズマは焦点付 近の短い部分のみであることがわかる。Fig. 4で は $10 \mu \mathrm{s}$ までガイド長が変化しない特性になって いるが，これは $10 \mu \mathrm{s}$ 以上放電誘導効果を持続す るプラズマの長さがギャップ長に対して長いた め生じたと考えられる。

本実験における放電状況の静止写真を Fig. 6に 示す。これは最も長いギャップにおけるArFレー ザーによる放電誘導であり, ギャップ長は水平 方向に $1 \mathrm{~m}$, 垂直方向に $0.1 \mathrm{~m}$ であり, 遅れ時間は $-1 \mu \mathrm{s}$ の時のものである。

\section{4. 考察}

4.1 紫外レーザーの放電誘導特性と誘雷シス テム 
これまでの実験結果より, 紫外レーザーパル スによりプラズマチャネルを生成し，不平等電 界下の気中放電を誘導することが可能であるこ とが実証された。特に今回の実験ではギャップ 長 $1 \mathrm{~m}$, 放電ガイド長 $0.5 \mathrm{~m}$ とこれまでの紫外レー ザーによる気中放電の誘導実験では最も長い放 電の誘導に成功した。この結果から, 複雑な自然 現象である雷も基本的には電気放電現象である ので, 紫外レーザーを用いて雷放電を誘導する ことは原理的には可能であると言える。

紫外レーザーには赤外レーザーにはない利点 がいくつかある。その一つは正極性放電の誘導 が可能であるという点である(Fig. 2)。放電ガイ ド効果に関しては負極性と比べると効果は低下 するが, 赤外レーザーのように正極性リーダが プラズマにまったく沿わないということはない。 また放電トリガ効果に関しては正極性の方が負 極性の場合より効果が持続するという結果に なっている。

紫外レーザーのもう一つの利点は放電を誘導 するのに必要なエネルギーが赤外レーザーより 少なくすむことである。単純に考えると放電を

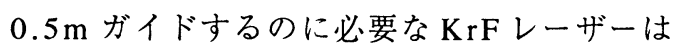
$750 \mathrm{~mJ}, \mathrm{ArF} レ ー サ ゙ ー て ゙ は 550 \mathrm{~mJ} \mathrm{であった。ここ}$ でレーザーパルスエネルギーと放電ガイド長の

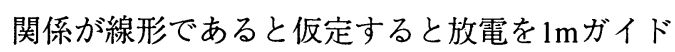

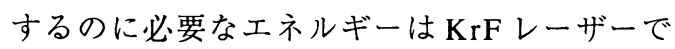

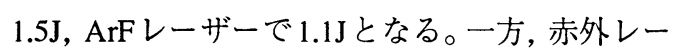
ザーでは最も効率のよい放電誘導は大阪大学が 得た結果であり, $100 \mathrm{~J}$ のパルスで $8.5 \mathrm{~m}$ を誘導し

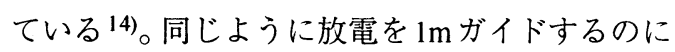
必要なエネルギーを求めると約 $11 \mathrm{~J}$ となり, 約 10 倍の差があることになる。

紫外レーザーにもいくつかの欠点がある。ま ず実験 3.1 の結果でも明らかなように放電のス パークオーバ電圧を低下させる能力（放電トリ ガ効果)にそしいことが挙げられる。この結果は レーザートリガギャップの実験から期待される 結果とは異なっているが, これはレーザートリ ガギャップ実験は数 $\mathrm{cm}$ 以下の小ギャップでかつ 平等電界下の放電を対象とするのに対して, 今 回の実験では長ギャップでかつ不平等電界下の 放電を対象としており，その差によるものと考
えられる。放電トリガ効果の不足は誘雷を考え た場合, レーザーを用いても他の高構造物に先 だって避雷塔からの上向き放電が発生しない可 能性が高いことを示している。よって, 紫外レー ザーを用いた場合は避雷塔を被遮蔽物程度に高 くしたり, 避雷塔の位置を雷雲の来る方向へ設 置するなどして, 雷雲と避雷塔の距離を被遮蔽 物との距離より小さくすることが必要になる。 なお, 放電トリガ効果の向上策として紫外レー ザーに赤外レーザーを重畳して, 紫外レーザー による長尺プラズマ中に高電離プラズマを生成 することも提案されている ${ }^{15)}$ 。

もう一つの欠点としてプラズマの放電誘導効 果の持続時間が数 $\mu \mathrm{s}$ と短いことがある。Fig. 4の 遅れ特性を見ても, ガイド効果でさえ $10 \mu \mathrm{s}$ しか 持続しない。さらに, Fig. 5より明らかなように 放電誘導可能なプラズマは集光レンズの焦点付 近のみであり, プラズマチャネルの中央部分に 限られている。雷放電は実験室内の放電に比べ て進展に要する時間が長いため, その間プラズ マの効果を持続させる必要がある。この対策の 一つとして他の種類のレーザーを重畳すること によりプラズマを加熱してその効果を維持する ことが提案されている16)。

4.2 紫外レーザーの伝搬特性と誘雷システム 紫外レーザーの利点の一つに伝搬特性がある。 すなわち赤外レーザーでは生成したプラズマに レーザー光自らが吸収, 散乱されてしまうとい う欠点があるが, 一般に波長が短いほどプラズ マによる吸収, 散乱の影響を受けにくいので, 紫 外レーザーでは生成したプラズマによる吸収, 散乱の影響は少ないと考えられる。この点を確 認するための実験を行った。まず,レンズにより ビームを集光し, 生成されたプラズマの後方に ジュールメータを置いてエネルギーを測定した。 次にレンズを使用せずにレーザーを伝搬させ， 同じ位置にジュールメータを置いてエネルギー を測定した。得られた測定值（パルスエネル

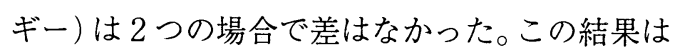
エキシマレーザーではプラズマ生成にほとんど エネルギーが消費されておらず，また散乱もな いことを示している。赤外レーザーでは 50J の 
$\mathrm{CO}_{2}$ レーザーパルスを例にとると, $10 \mathrm{~m}$ の凹面鏡 により $2 \mathrm{~m}$ 程度のプラズマを生成すると，40J 程 度のエネルギーがプラズマへの吸収, 散乱で損

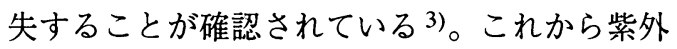
レーザーの損失は赤外レーザーと比べて極めて 少ないことがわかる。レーザー生成プラズマは 主にレーザーのパラメータの中で主にパルスエ ネルギーとパワー密度の2つに依存するが, この 実験結果は紫外レーザーでは, パルスエネル ギーよりもプラズマ生成のしきい值であるパ ワー密度が大きな比重を占めることを示してい る。

ここで放電誘導可能なプラズマを生成するた めのパワー密度の推定を行う。放電チャネルが 直線状でなくなる点のレーザーのパワー密度が 放電誘導のしきい值と考えられるが, 放電チャ ネルがプラズマから逸れる原因はプラズマパラ メータだけでなく, 電界の大きさや分布も大き く関係している。そのため厳密には, 放電誘導可 能なプラズマを生成するためのパワー密度のし きい值は局所的な電界の関数でもある。本実験 では非対称のギャップ配置になっており, ギャップ中心部の電界分布は複雑である。この ため,ここでは高圧電極近傍の高電界領域にお いて放電がレーザー生成プラズマから逸れるポ イントのビーム断面積を測定し, パワー密度を 推定することとした。この条件は自然雷を考え た場合，避雷針の先端における状況を模擬する ものである。ビーム断面積は写真フィルム(ポラ ロイドフィルム，667 使用)にレーザーを照射し た時のフィルムの変色により推定したものであ

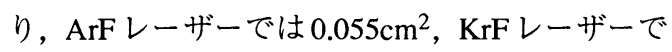
は $0.033 \mathrm{~cm}^{2}$ であった。パルス幅はカタログ值を 用いて ArFレーザーで20ns, KrFレーザーで25ns とした。これらの值およびエネルギー值からパ ワー密度を計算すると ArF レーザーで $0.5 \mathrm{GW} /$

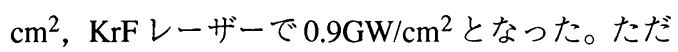
しここではビーム断面における強度プロファイ ルを一様と仮定しているが, 実際は中心部分が 高く周囲が低いプロファイルになっており, 実 際の值はここで求められた值より大きくなると 考えられる。

中村らも放電誘導可能なプラズマチャネル生

成のためのしきい值を導出している 17)。彼らの 值は $0.72 \mathrm{GW} / \mathrm{cm}^{2}$ であり, 我々の值 $0.9 \mathrm{GW} / \mathrm{cm}^{2}$ と ほほ同じである。この2つはまったく異なる実験 結果に基づくものであり, いくつかの仮定の上 に導出されたものであるが，この一致はこれら のしきい值が実際の值から大きくはずれてはい ないことを示していると考えられる。

\section{3 紫外レーザーによる誘雷システム}

ここで紫外レーザーを用いた誘雷システムに ついて検討してみる。紫外レーザーによる誘雷 システムとしては中村らによる提案がある17)。 このシステムを参考に, 新たに得られた実験結 果を考慮して誘雷システムの検討を進める。こ れまでの実験結果が示すように紫外レーザーは 放電ガイドの効率が良いことから, 雷放電をト リガするのではなく雷放電路を制御するガイド 型誘雷に適していると見られる。使用する紫外 レーザーはプラズマを生成するパワー, エネル ギーが必要であるので, エキシマレーザーが最 有力候補になる。また，レーザーは少なくとも $100 \mathrm{~m}$ 以上は伝搬する必要があるため, 空気中の 分子による吸収, 散乱の効果は重要である。この

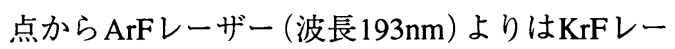
ザー（波長 $248 \mathrm{~nm}$ ）あるいは XeClレーザー（波 長 $308 \mathrm{~nm} ）$ が適当であろうと考えられる。さら に，出来るだけコンパクトなシステムにするた め,レンズ等による光学系は用いずに, 雷雲に向 かってそのままレーザーを照射する方式を考え る。

以上の点を考慮して誘雷用レーザーの仕様の 概要を推定してみる。

レーザーの伝搬モードが TEM 00 とするとビー ム断面積と伝搬距離の関係は次式のように表す ことが出来る ${ }^{18)}$ 。

$$
\begin{aligned}
& b=\pi W_{0}^{2} / \lambda \\
& \theta=\lambda / 2 \pi W_{0} \\
& W(z)^{2}=W_{0}^{2}\left(1+(z / b)^{2}\right) \\
& \lambda \quad: \text { レーザーの波長 } \\
& W(z): \text { レーザー照射口からの距離 } \mathrm{z} \text { における }
\end{aligned}
$$




$$
\begin{array}{ll} 
& \text { ビーム半径 } \\
W_{0} & : \text { レーザー照射口付近のビーム半径 } \\
\theta & : \text { レーザーのビーム発散角 (全角) } \\
b \quad: \text { コンフォーカル距離(ビームの平衡伝 } \\
\\
\quad \text { 搬の指標) }
\end{array}
$$

一般に伝搬距離 $z$ が $b$ より長くなるとビームは 急速に発散するため, bはコンフォーカル距離と 呼ばれレーザービームの平衡伝搬の指標として 扱われる。

雷を導く避雷塔の高さを $100 \mathrm{~m}$, 雷放電をガ イドする長さを $100 \mathrm{~m}$ とおく。避雷塔は高めであ るが,これは4.1において検討したようにエキ シマレーザーは放電トリガ効果があまりないた めである。プラズマはレーザー照射口から $200 \mathrm{~m}$ の位置まで生成される必要があるので, $b=200 \mathrm{~m}$ となる。用いるレーザーは KrFレーザー（波 長 $248 \mathrm{~nm}$ ) とし,レーザーのパルス幅 $\tau$ は一般的 な放電励起 KrF レーザーの值である $25 \mathrm{~ns}$ (FWHM)を，放電誘導のためのしきい值は前節 で求めた $0.9 \mathrm{GW} / \mathrm{cm}^{2}$ を用いる。また放電誘導 可能なプラズマチャネルの半径は $1 \mathrm{~mm}$ とする。

以上の仮定の上で必要なレーザーのパルス エネルギーを推定してみる。(1)式よりレーザー 照射口付近のビーム半径 $W_{0}$ は $3.97 \mathrm{~mm}$ と求まる。 ここで(3)式を用いると，レーザーが $200 \mathrm{~m}$ 伝搬 した地点ではビーム半径 $W$ は広がって $1.414 W_{0}$ になっていることがわかる。この時ビームの 中心から半径 $0.5 \mathrm{~mm}$ 以内においてパワー密度 がプラズマチャネル生成のしきい值以上でなく てはならない。ビーム断面におけるパワー密 度は次式で与えられる。

$$
\begin{aligned}
& I=I_{0}\left(W_{0} / W\right)^{2} \exp \left(-2(r / W)^{2}\right) \\
& r: \text { : }- \text { 中心からの径方向の距離 } \\
& I_{0}: \text { ビーム中心におけるパワー密度 }
\end{aligned}
$$

この式より $z=200 \mathrm{~m}, r=0.5 \mathrm{~mm}$ の点におけるパ ワー密度は $0.469 I_{0}$ となる。この值が $0.9 \mathrm{GW} / \mathrm{cm}^{2}$ 以上となるとして $I_{0}$ を求め, 次式でパルスエネル ギーを求めると 12Jという值が得られる。

$$
E=\pi W_{0}^{2} I_{0} \tau / 2
$$

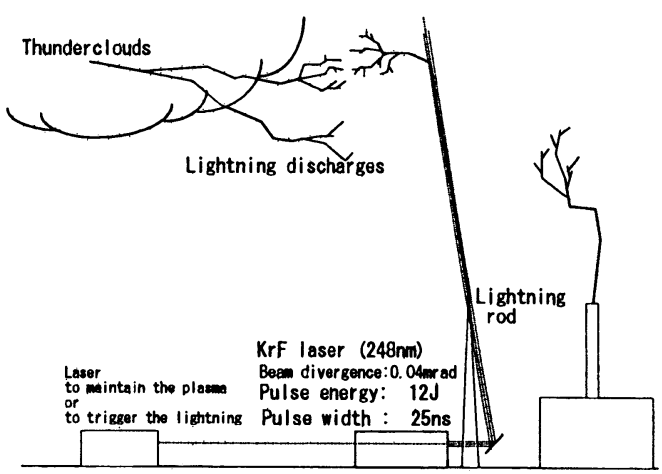

Fig. 7 Basic concept of the artificial triggered lightning using ultraviolet lasers.

この值は, 現在開発されている放電励起方式 $\mathrm{KrF}$ レーザーの最大值程度の大きさであり 19), ビー ム質やパルス幅等多くの要求を考慮しても，実 現可能な值と考えられる。Fig. 7 に検討したレー ザー誘雷システムの概要を示す。

既に紫外レーザーによる誘雷システムについ ては中村らによっても検討がなされているが17), 彼らの試算ではパルスエネルギー 3.67J, パルス 幅 $10 \mathrm{~ns}$ ，ビーム径 $3.98 \mathrm{~mm} に よ り ~ 200 \mathrm{~m}$ の距離に わたり雷放電を誘導できるとしている。本論文 において検討したシステムとの差が生じる主な 原因はパルス幅および生成するプラズマの半径 の設定にあると考えられる。彼らはパルス幅を $10 \mathrm{~ns}$ と仮定しており，我々の $2 / 5$ である。数值的 にはパルス幅を小さくすると，エネルギー值を 小さく出来るので，レーザー装置としては小型 化につながる。しかし,パルス幅が短いと増幅器 の中をビームが通過してもエネルギーの増加率 は小さい。このため, 短いパルス幅でエネルギー を増幅するためには，多段増幅が必要になるの で最終的なシステムとしては大型化する可能性 がある。さらに, 短いパルス幅を短くすることは 共振器の中でのビームの往復回数が減ることと なり,ビーム質が劣化する原因になる。従ってパ ルス幅の短縮が有効かどうかについては更なる 検討が必要である。また,プラズマチャネルの径 はレーザーエネルギー值と直接結びついており, プラズマチャネルの径を細くすれば必要なエネ ルギー值はさらに小さくすることが可能である。 中村らの試算ではプラズマチャネルの径は考慮 していないが，同様の条件で計算をしてみると 
我々より細い径になっている。しかし, 径が細い と, 低温の中性原子との衝突や拡散の効果が強 まり,プラズマの減衰が早くなる。

一方, 我々の検討ではビーム質を理想的な条 件に設定しているので, ビーム発散角は $0.04 \mathrm{mrad}$ と極めて小さくなっている。一般に, 大 出力エキシマレーザーのビーム発散角は数 $\mathrm{mrad}$ 程度と大きいので, 注入同期方式や不安定共振 器等を使用して発散角を抑える必要がある。こ のビーム発散角が大きくなると,(1)(2)式からわか るようにコンフォーカル距離 $b$ が減少し, $200 \mathrm{~m}$ の点のビーム断面積が大きくなってしまう。仮 に $\theta=0.1 \mathrm{mrad}$ とすると, $200 \mathrm{~m}$ の地点でビーム断 面積は約 40 倍になり, 必要なエネルギーも大幅 に増加してしまう。したがってエキシマレー ザーを用いた誘雷システムではレーザーの伝搬 特性の向上が極めて重要なポイントであること がわかる。

\section{5. 結 論}

紫外レーザーによる誘雷システムの検討をす るために, $30 \mathrm{~cm}$ 以上のギャップ長にて気中放電 の誘導実験を行った。その結果, 最大 $1 \mathrm{~m} の$ ギャップ長にて約 $50 \mathrm{~cm}$ の距離にわたり放電をガ イドすることに成功した。さらに紫外レーザー の放電誘導特性の測定から, 紫外レーザーは赤 外レーザーとは異なった放電誘導特性を持つこ とが明らかになった。紫外レーザーの利点とし ては正極性放電の放電ガイドが可能, 放電ガイ ドにおけるエネルギー効率が良好，レーザーの プラズマ中の伝搬特性がよいことなどが明らか になったが, 一方, プラズマチャネルの放電誘導 が可能な時間が短いことや放電トリガの能力に そしいなどの欠点も明らかになった。これらの 結果に基づき紫外レーザーを用いた実誘雷シス テムの概念設計を行い，その実現が可能である ことを示した。なお，今後より詳細に検討を進め るためには，紫外レーザーによるプラズマ生成 とそれを用いた放電誘導メカニズムの定量的な 解明が重要である。また長ギャップの放電の誘 導特性や長距離の大気中の伝搬特性の解明のた めに大出力紫外レーザーによる大規模実験もそ
の実施が望まれる。

\section{参 考 文 献}

1) 新藤孝敏, 鈴木俊男: 電力中央研究所調査報 告 182010 (1982).

2) G. N. Aleksandrov et al.: Sov. Tech. Phys. Lett. 15 (1989) 628.

3) 広橋道夫, 栄千治, 坂井辰彦, 内山太郎: 放 電研究 No.123 (1989) 45.

4) 藤原閲夫, 井澤靖和, 河崎善一郎, 松浦虔士, 山中千代衛：レーザー研究 19 (1991) 528.

5) 三木 恵, 和田 淳 : 大気電気研究会 No. 45 (1994).

6) 内海通弘, 入野仁, 慎野武男, 田中祀捷, 村 岡克紀, Grigory Baitsur, 木下文宏, 片平治, 本田親久, 辻利則, 赤崎正則: 電気学会論文 誌 115A (1995) 614.

7) J. Sasaki et al.: J. Appl. Phys. 60 (1986) 3845

8) 久保, 神野雅文, 森岡仁志, 尾崎隆英, 板谷 良平, 園井康夫, 永井敏雄: 電気学会高電圧 研究会 HV-91-96 (1991) 71.

9) 三木 恵, 和田 淳: 電気学会論文誌 $114 \mathrm{~A}$ (1994) 727.

10) C. A. Frost et al.: Appl. Phys. Lett. 41 (1982) 813.

11) R. L. Carson et al.: J. Appl. Phys. 61 (1987) 12.

12) P. W. Werner et al.: Phys. Rev. Lett. 73 (1994) 2986.

13) J. R. Woodworth et al.: J. Appl. Phys. 56 (1984) 1382.

14) 永井敏雄, 園井康夫, 藤原閲夫, 井澤靖和, 河崎善一郎, 松浦虔士, 山中千代衛: 電気学 会放電高電圧合同研究会 ED-92-71 (1992).

15) 神野雅文, 久保, 板谷良平: 電気学会論文誌 115-A (1995) 595.

16) Xin Miao Zhao et al.: CLEO'95, CWE2, (1995) 182.

17) 中村圭二, 鈴木孝光, 山部長兵衛, 堀井憲爾： 電気学会論文誌 113-B (1993) 1265.

18)レーザー学会編：「レーザーハンドブック」 オーム社。

19) 挟間寿文, 宮崎健創, 山田家和勝, 佐藤卓蔵： 量子デバイス研究会資料 QCD-89-10 (1989). 